\title{
Article
}

Michael William Thorpe* and Nuno Carlos Leitão

\section{Determinants of United States' Vertical and Horizontal Intra-Industry Trade}

\begin{abstract}
This paper investigates bilateral intra-industry trade between the United States and its major trading partners over the period 1995-2008. Intraindustry trade (IIT) is decomposed into horizontal (HIIT) and vertical (VIIT) components. HIIT dominates the total two-way trade of the United States and its share relative to VIIT has been rising over time, particularly with neighbouring trade partners and with China. Using pooled panel data, country-level determinants of IIT, HIIT and VIIT are investigated. The results, overall, tend to conform with a priori expectations and provide empirical support for a number of propositions suggested by theory. Findings indicate that the relative similarity of the economies of trading partners, their geographical proximity, FDI and overall market size are important influences on bilateral HIIT flows for the United States. VIIT, on the other hand, is found to be driven in large part by economic differences between partners as well as the market size and closeness of trading partners.
\end{abstract}

Keywords: intra-industry trade, horizontal intra-industry trade, vertical intraindustry trade, United States

JEL Classifications: F14, F12, C20

*Corresponding author: Michael William Thorpe, Department of Economics, Curtin Business School, Perth, WA 6845, Australia, E-mail: m.thorpe@curtin.edu.au

Nuno Carlos Leitão, Department of Economics, Polytechnic Institute of Santarém, and CEFAGE, Èvora University, Evora, Portugal, E-mail: nunocarlosleitao@gmail.com

\section{Introduction}

A concentration of global trade flows within industries rather than between industries has been observed to be a growing phenomenon for several decades, particularly among developed countries. The resulting simultaneous export and import by a country of products within a particular industry grouping has been 
called intra-industry trade (IIT) or two-way trade. What has now become a considerable literature on IIT began with work by Verdoorn (1960) and Balassa (1966) observing trade patterns between partner countries in the emerging European Economic Community (EEC). Recent surveys of developments in the IIT area are provided by Greenaway and Milner $(2005,2006)$.

Empirical work in the area began to receive growing attention after Grubel and Lloyd (1975) introduced an index that provided an operational measure of two-way trade. A growing weight of evidence has emerged pointing to the fact that IIT becomes relatively more important for a country as development proceeds and is a more intense phenomenon in manufacturing trade between countries at similar levels of economic development (Hummels and Levinshon 1995). Such observations run counter to the predictions of the factor endowment trade model that deals with explaining inter-industry specialization arising from the expansion of bilateral trade between dissimilar economies.

Seminal work by Krugman (1979) and Lancaster (1980) developed theoretical frameworks which differed from the traditional H-O explanation, introducing models of monopolistic competition that identified increasing returns to scale along with the demand by consumers for varieties of (horizontally) differentiated products as key drivers of IIT. Further theoretical contributions by Helpman (1981), Eaton and Kierzkowski (1984) and Helpman and Krugman (1985) predicted that similarities in relative per capita income and resource endowments along with country size (given the greater opportunities this presents for scale economies) were expected to be positively related to the share of IIT in a country's total trade.

New international trade models have sought to decompose IIT into horizontal and vertical components. Horizontal IIT (HIIT) refers to two-way trade in products with different actual or perceived attributes (within similar qualities) and has effectively been the focus of those empirical studies which address IIT and which do not explicitly distinguish between the different "types" of two-way trade. Work by Falvey (1981), Shaked and Sutton (1984), Flam and Helpman (1987) and Falvey and Kierkowski (1987) provided a theoretical basis for IIT involving two-way trade in products of different quality, so-called vertical intraindustry trade (VIIT). On the supply side, different factor endowments are considered to result in countries specializing in different quality products. Countries with relatively higher capital to labour ratios, for example, are deemed to have comparative advantage in higher-end quality products. This type of trade is viewed as consistent, therefore, with the traditional factor endowment model, but with a focus on different quality goods being traded rather than different goods, per se. On the demand side, relative incomes of consumers will 
determine demand for different quality goods. Differences in per capita income, therefore, are expected to be positively related to the share of VIIT in two-way trade.

VIIT is also consistent with trade fragmentation or outsourcing, with focus on the production process rather than the end-use characteristic (Thom and McDowell 1999; Lloyd 2004). The studies of Clark (2006), Wakasugi (2007) and Leitão, Faustino, and Yoshida (2010) highlight the importance of fragmentation where two-way trade reflects the exchange of intermediate goods at different stages of production. In such cases, differences in relative factor endowments will be important although at sub-industry level rather than at industry level as is the case with inter-industry trade.

Given that different determinants are expected to be at play, the distinction between HIIT and VIIT has become increasingly important in empirical studies. Several recent studies have found that VIIT dominates HIIT in a number of bilateral trade relationships (Faustino and Leitão 2007; Blanes and MartinMontaner 2006; Murshed 2001), while Fontagne, Freudenberg, and Gaulier (2006) report that the increase in IIT at the world level since the 1980s has been primarily due to the growth in two-way trade of vertically differentiated products. Failure to separate out the different forms of IIT in empirical work is likely to be an important reason why varying results have been evident in econometric analyses of the determinants of two-way trade.

This paper analyses the country-specific determinants of IIT of the United States and its major trading partners in East Asia, Europe and North America over the period 1995-2008. Both HIIT and VIIT are investigated. Fontagne, Freudenberg, and Gaulier (2006) have noted that although the largest shares of IIT among trading partners are observed in Europe, the largest flows of bilateral IIT by value are recorded for United States trade with both Canada and Mexico. United States trade with Japan is also reported as having significantly high levels of IIT. In a study covering the period 1996-2005, Chang (2009) has found that while VIIT was relatively significant in trade between Asian and European countries, HIIT dominated two-way trade between Asia and the United States. Manufacturing IIT for the United States, meanwhile, has been observed to account for around 70 per cent of the country's total manufacturing trade (Brulhart and Thorpe 2001).

An earlier study of the United States by Clark and Stanley (2003) investigated the factors influencing IIT between that country and major industrialized nations, looking at both country-level and industry-level determinants. The study was based on 1992 data and found, contrary to stated expectations, that IIT was positively related to differences in the capital to labour ratios of trading partners. While this result does not conform to the factor endowment-based 
explanation, it is suggestive that disaggregating the measure of IIT could help shed light on the factors at play. Moreover, their finding that there is no support for a positive link between IIT trade share and scale economies could also be influenced by the measurement of IIT employed. A more recent study by Zhang and Clark (2009) does investigate HIIT and VIIT for the United States with its trading partners. This approach uses industry-level characteristics (based on 1992 data) and country-level determinants (based on 1997 data) to assess the determinants of disaggregate two-way trade in 1997. The study also notes that while IIT dominated United States trade in 1997, the HIIT share of this trade was three times higher than that for VIIT.

This study uses a static panel data approach, employing a fixed-effects model. The structure of the paper is as follows. Section 2 discusses the measurements of intra-industry trade that are employed. This is followed by a descriptive analysis of observed IIT patterns of United States' IIT. Section 4 provides an outline of the country-specific explanatory variables to be included in the analysis and the hypotheses under investigation. The model specification to be employed is also presented in this section, followed by the empirical results in Section 5. We end with some concluding comments.

\section{Measures of intra-industry trade}

Several methods have been proposed to disentangle HIIT and VIIT. There are two widely used approaches. One, introduced by Greenaway, Hine, and Milner (1994), decomposed a Grubel-Lloyd index, while another categorised trade flows and computed the share of each category in total trade (Abd-el-Rahman 1991; Fontagne and Freudenberg 1997; Fontagne, Freudenberg, and Gaulier 2006). Both these approaches rely on a link between measured unit values and the determined quality of traded products. HIIT is deemed to be present if there is some pre-determined degree of similarity in unit values in the observed two-way trade in a particular disaggregated trade category. Otherwise the two-way trade is viewed as VIIT. Zhang and Clark (2009) and Azhar and Elliott (2006) have highlighted some problems with these methodologies, suggesting among other things, that the measure of VIIT is likely to be inflated.

In an alternative formulation, Thom and McDowell (1999) and Thorpe and Zhang (2005) have focused on the organization of production in a measurement of VIIT. In this approach, two-way trade is considered to reflect the exchange between countries of intermediate goods or a result of trade in components that is matched to some degree by trade in related final goods. In either case, the 
production process is vertically disintegrated across countries, shaped by comparative advantage.

The present study uses the methodology of Kandogan (2003) for separating IIT into its components. In this methodology, HIIT is defined as the overlapping trade in a broad industry category that consists of two-way trade within narrowly defined industries. VIIT is the balanced trade within a broadly defined industry-class that comprises exports and imports across narrowly defined industries (Bergstrand and Egger 2006). HIIT and VIIT sum up to overall IIT. Inter-industry trade (INT) is then the unmatched part of total trade (TT). The methodology of Kandogan (2003) is summarized as follows:

$$
\begin{gathered}
\mathrm{TT}_{i}=X_{i}+M_{i} \\
\mathrm{IIT}_{i}=\mathrm{TT}_{i}-\left|X_{i}-M_{i}\right| \\
\mathrm{INT}_{i}=\mathrm{TT}_{i}-\mathrm{IIT}_{i} \\
\mathrm{HIIT}_{i}=\sum\left(X_{i k}+M_{i k}-\left|X_{i k}-M_{i k}\right|\right) \\
\operatorname{VIIT}_{i}=\mathrm{IIT}_{i}-\mathrm{HIIT}_{i}
\end{gathered}
$$

This approach calculates IIT, HIIT and VIIT in levels and not the corresponding shares in total trade. These measures are used in the econometric analysis below. In the descriptive discussion of United States' IIT in the next section, we employ normalized aggregated indices of the different measures as follows, where IIT between partners $i$ and $j$ is determined for industry $k$ :

$$
\begin{gathered}
\mathrm{IIT}_{i j}=1-\frac{\left|\sum_{k=1}^{K} X_{i j k}-\sum_{k=1}^{K} M_{i j k}\right|}{\sum_{k=1}^{K} X_{i j k}+\sum_{k}^{K} M_{i j k}} \\
\operatorname{HIIT}_{i j k}=1-\frac{\left|X_{i j k}-M_{i j k}\right|}{X_{i j k}+M_{i j k}} \\
\operatorname{VIIT}_{i j}=\operatorname{IIT}_{i j}-\operatorname{HIIT}_{i j}
\end{gathered}
$$




\section{Patterns of U.S. intra-industry trade}

Changes in the pattern of United States' HIIT and VIIT with major trading partners between 1995 and 2008 are provided in Table 1. This selection of countries accounts for over 90 per cent of United States' trade in manufactured goods over this period. The figures provide some insights as to the nature of resulting structural shifts which occurred in the country's bilateral manufacturing trade. This was a time of significant change in the external trading environment impacting both the United States and the global trading environment more generally. In 1994, Mexico joined with the United States and Canada to establish the North American Free Trade Agreement (NAFTA) while 1995 saw a successful completion of the Uruguay Round of multilateral trade negotiations with the implementation of this agreement taking place over the following five years. The accession of China to the World Trade Organisation (WTO) in 2001 resulted in further ongoing impacts on the structure of global trade patterns.

Table 1: U.S. United States' IIT by trading partner - selected years.

\begin{tabular}{llllll}
\hline Partners & \multicolumn{2}{c}{1995} & & \multicolumn{2}{c}{ 2008 } \\
\cline { 2 - 3 } \cline { 5 - 6 } & HIIT & VIIT & & HIIT & VIIT \\
\hline Brazil & 0.82 & 0.10 & 0.97 & 0.03 \\
Belgium-Luxembourg & 0.51 & 0.49 & 0.68 & 0.32 \\
Canada & 0.91 & 0.08 & & 0.85 & 0.15 \\
China & 0.56 & 0.44 & & 0.77 & 0.23 \\
Denmark & 0.83 & 0.17 & 0.28 & 0.72 \\
France & 0.90 & 0.10 & 0.75 & 0.25 \\
Germany & 0.65 & 0.35 & 0.59 & 0.41 \\
México & 0.92 & 0.08 & 0.85 & 0.15 \\
Netherlands & 0.28 & 0.72 & 0.58 & 0.42 \\
Portugal & 0.88 & 0.12 & 0.86 & 0.14 \\
Spain & 0.84 & 0.16 & 0.96 & 0.04 \\
Japan & 0.51 & 0.49 & 0.42 & 0.58 \\
Korea & 0.98 & 0.02 & 0.78 & 0.22 \\
Thailand & 0.58 & 0.42 & 0.14 & 0.86 \\
Italy & 0.52 & 0.48 & 0.29 & 0.72 \\
United Kingdom & 0.98 & 0.02 & 0.95 & 0.05 \\
\hline
\end{tabular}

Source: OECD (2010); Authors' calculus.

HIIT is seen to be particularly important for the United States with its close regional neighbours including Brazil and its NAFTA partners. In the case of Mexico, there has been a small shift towards VIIT, reflecting a sharp rise in 
investment links between the partners, with more vertical integration of production processes occurring across borders. The relationship with major trading partners in East Asia and in Europe is generally characterised as exhibiting relatively much smaller shares of HIIT. In the case of China, HIIT has become more significant, while becoming much less so for Japan and Korea.

The shifting pattern of Unites states' IIT is an important issue for analysis given its observed share in overall trade. As has been observed elsewhere, the fact that different forces are seen as driving HIIT and VIIT has implications for the adjustment costs within a country associated with an expansion in trade (Greenaway, Hine, and Milner 1994; Brulhart and Elliott 2002; Greenaway and Milner 2006). It is suggested that factors are likely to be less mobile within vertically differentiated industries when compared to horizontally differentiated ones since the skill requirements are considered greater in the former. The greater the expansion of trade that is characterised as HIIT, therefore, the less pressure is expected for factor market adjustment, a reflection of the so-called "smooth adjustment thesis". Further work in this area would be fruitful.

\section{Econometric model}

Vertical and horizontal intra-industry trade between United States and major trading partners for the period between 1995 and 2008 are constructed from OECD data at the five-digit level of the Standard International Trade classification (SITC) (OECD 2010). Geographical distances were obtained from Fitzpatrick and Modlin (1986). Other explanatory variables are taken from The International Monetary Fund, Balance of Payments database, supplemented by data from the United Nations Conference on Trade and Development and official national sources.

\subsection{Explanatory variables and hypotheses}

In investigating relationship in the area of international trade, it is often difficult to test and operationalise relationships because of the lack of a generally applicable theoretical model. This is particularly problematic when considering models that assume imperfectly competitive markets and differentiated products because a variety of theories and methodologies can be employed. A particular problem relating to some of the theoretical modeling has been that propositions that have been formulated regarding the likely determinants of IIT have presupposed trade in horizontally differentiated products. 
The choice of variables used in testing hypotheses must, therefore, be carefully assessed. Although there is a broad consensus from empirical work as to the country-level determinants of IIT, the consideration of HIIT and VIIT as the dependent variable in econometric analysis requires attention as different forces are likely to be at work.

Drawing on the theory outlined above, and focusing on country specific influences, the following variables have been considered and a number of hypotheses are presented.

The economic differences between the United States and its trading partners are captured in the variable $D G D$ which measures differences in GDP per capita (PPP, in current international dollars) for each bilateral pairing. There exists debate in the literature as to whether such a measure is serving as a proxy for factor endowments or for consumer tastes. Following Helpman (1987), Helpman and Krugman (1985) and Greenaway, Hine, and Milner (1994) this variable can be considered to reflect relative factor endowments and hence levels of economic development. In this sense then, the greater the difference in per capita incomes the greater will be the opportunity for vertical integration of production across economies and hence VIIT. For HIIT a negative relationship is expected based on the importance of similarity in factor endowments for the ability to produce similar, differentiated products.

In line with Linder (1961), an overlap in demand patterns as reflected in similarities in per capita incomes across trading partners is expected to create wider markets for the exchange of differentiated products of similar qualities and therefore provide opportunities to exploit scale economies, increasing IIT and HIIT. Differences in tastes, however, will allow for greater trade in products of varying qualities (reflective of VIIT).

Hypothesis 1: There is a negative (positive) relationship between differences in per-capita income and IIT and HIIT, (VIIT).

According to Helpman and Krugman (1985), the more countries differ in relative size, the less likelihood there is for IIT (and HIIT). Two variables are included to control for relative size effects (Hummels and Levinshon 1995). MinGDP is a measure of the lower value of GDP for the United States and each partner country, whereas MaxGDP represents the higher value in each such case. Flam and Helpman (1987) have employed a similar specification in a study of NorthSouth trade incorporating vertically differentiated products. Following the literature, the closer trading partners are in terms of their relative (economic) size, the greater is the expected share of both HIIT and VIIT.

Hypothesis 2: There is a positive (negative) correlation between MinGDP (MaxGDP) and IIT, HIIT and VIIT. 
Lancaster (1980) has shown that the larger the overall market, the greater the opportunities for product differentiation as countries specialise in "niche" segments and achieve economies of scale. Drawing on Helpman (1981) and Balassa (1986), larger markets also allow more opportunity for trade overlap and a higher and more diverse demand for foreign (differentiated) products. The variable DIM is defined here as the average of the GDP of the United States and that of the trade partner. Looking at the supply side, this variable serves as a proxy to capture the potential for economies of scale and is expected to be positively related to both IIT and HIIT. On the demand side, a larger market suggests that a wider range of qualities will be demanded. Jones and Kierzkowski (2004) and Grossman and Helpman (2005) have posited a positive relationship between economic size and VIIT.

Hypothesis 3: There is a positive relationship between DIM and all IIT measures.

Based on Falvey (1981) (higher) product quality is linked with (greater) capital intensity and as a result countries will specialise in particular qualities of differentiated products based on their relative factor endowments. Lloyd (2004) suggests, therefore, that VIIT can be explained by differences in comparative advantage and the variable INT, a measure of inter-industry trade, is included in line with previous studies to reflect the forces underpinning such differences (Grubel and Lloyd 1975; Kandogan 2003). A positive relationship is expected between INT and VIIT while the opposite relationship is predicted in the case of IIT and HIIT.

Hypothesis 4: There is a positive relationship between forces driving comparative advantage (INT) and VIIT. A negative relationship exists between INT and both HIIT and IIT.

The distance between trading partners can be viewed as indicative of relative social and cultural proximity as well as reflecting transport costs. Balassa and Bauwens (1987) and Krugman $(1979,1980)$ argue that IIT (HIIT) will be greater the closer geographically are trading partners. Bergstrand and Egger (2006) provide a clear insight into the relationship between the share of IIT and trade costs, providing sound theoretical and empirical evidence to support the tenet that trade costs should negatively impact the share of IIT of a country. Several detailed arguments are outlined in Zhang, van Witteloostuijin, and Zhou (2005) explaining the ways in which geographical distance can impact both VIIT and HIIT. They conclude that proximity is likely to be more important in the case of HIIT. Gray and Martin (1980) have argued that since demand elasticities for 
differentiated products are relatively high, IIT, effectively HIIT, is likely to be more sensitive to variations in transport costs than IT. The variable DISTxDGDP represents geographical distance between trading partners multiplied by DGDP (between the United States and each partner country). IIT, HIIT and VIIT are all expected to show a negative relationship with this variable.

Hypothesis 5: There is an inverse relationship between DISTxDGDP and all IIT measures.

The relationship between IIT and the level of foreign direct investment (FDI) in a particular industry is somewhat ambiguous as FDI may be a substitute for the trade (Gray 1988). Markusen (1994) and Helpman (1987) consider that IIT, HIIT and VIIT shares will all be positively associated with a trading partner's FDI inflows. Based on the product life-cycle theory and to the extent that FDI increases the potential for a wider range of products to be produced, then FDI is expected to be positively associated with VIIT. This is particularly likely if the FDI is efficiency-seeking. To the extent that FDI is market oriented then FDI will reduce trade. In the case of HIIT the relationship with FDI is considered indeterminate, and will depend on the type of FDI involved. The variable FDI is a measure of the annual inward FDI flow to the United States from each trading partner.

Hypothesis 6: A positive relationship exists between FDI and VIIT. The relationship between FDI and both IIT and HIIT is indeterminate.

\subsection{Model specification}

In this study, hypotheses are drawn from a wide body of theoretical work using the gravity model that has provided a successful framework for explaining bilateral international trade flows in such circumstances (Anderson and van Wincoop 2004; Hummels and Levinsohn 1995; Anderson 1979). Darku (2009) presents an excellent, recent review on the standard gravity model. In many areas of applied economics it is difficult test and operationalise relationships because of a single, encompassing model. When dealing with models of imperfect competition and differentiated products this is particularly problematic. McCloskey (1988) provides support for the methodological approach taken here in including explanatory variables from across a number of trade theories.

The analysis of the determinants of IIT as well as its components (HIIT and VIIT) is undertaken using a panel approach. The model specifications 
considered were pooled OLS, fixed effects (FE) and random effects (RE) estimators. A fixed effects model was selected based on the Hausman test. This choice is supported also by the fact that the data set used captures most of United States' trade with all partners. We take natural logarithms for all variables. Consistent with the hypotheses outlined above, the model is given as:

$$
\begin{aligned}
\operatorname{LogIIT}_{i t}= & \beta_{0}+\beta_{1} \operatorname{LogDGDP}_{i t}+\beta_{2} \operatorname{LogMinGDP}_{i t}+\beta_{3} \operatorname{LogMaxGDP}_{i t} \\
& +\beta_{4} \operatorname{LogDIM}_{i t}+\beta_{5} \operatorname{LogINT}+\beta_{6} \operatorname{LogFDI} \\
& +\beta_{7} \operatorname{LogDISTxDGDP}_{i t}+\delta t+\eta_{i}+\varepsilon_{i t}
\end{aligned}
$$

where: $\eta i$ is the unobserved time-invariant specific effects; $\delta_{t}$ captures a common deterministic trend and $\varepsilon_{i t}$ is a random disturbance assumed to be normally distributed with $\left(\varepsilon_{i t}\right)=0$ and $\operatorname{Var}\left(\varepsilon_{i t}\right)=\sigma^{2} \succ 0$.

\section{Empirical results}

The descriptive statistics for the panel are presented in the Appendix. Fixed effects estimates are reported in Table 2. The general performance of the three

\begin{tabular}{|c|c|c|c|}
\hline \multirow[t]{2}{*}{ Variables } & IIT & HIIT & VIIT \\
\hline & Coefficient & Coefficient & Coefficient \\
\hline LogDGDP & $-8.939(-2.285)^{* *}$ & $-31.046(-2.535)^{* *}$ & $10.466(1.863)^{*}$ \\
\hline LogMinGDP & $0.8893(-3.226)^{* * *}$ & $3.424(3.967) * * *$ & $0.722(1.884) *$ \\
\hline LogMaxGDP & $-0.045(-0.233)$ & $0.730(1.524)$ & $0.455(1.034)$ \\
\hline LogDIM & $12.421(2.909) * * *$ & $36.561(2.751)^{* * *}$ & 11.889 (1.887)* \\
\hline LogINT & $-0.068(-2.981)^{* * *}$ & $-0.466(-5.794) * * *$ & $0.912(24.608) * * *$ \\
\hline LogFDI & $0.077(3.469) * * *$ & $0.198(2.802) * * *$ & $0.410(0.139)$ \\
\hline LogDISTxDGDP & $-0.327(-5.184)^{* * *}$ & $-0.346(-2.693) * * *$ & $0.080(1.316)$ \\
\hline Hausman $\left(X^{2}\right)$ & $170.73^{* * *}$ & $194.46 * * *$ & $33.67^{* * *}$ \\
\hline Adj. $R^{2}$ & 0.90 & 0.864 & 0.959 \\
\hline Observations & 252 & 252 & 252 \\
\hline
\end{tabular}
equations is satisfactory.

Table 2: Fixed effects model estimates.

Notes: $T$-statistics (heteroskedasticity corrected) are in brackets; $* * * / * * / *-$ Statistically significant, respectively, at the $1 \%, 5 \%$, and $10 \%$ levels; The Hausman test has $X^{2}$ distribution and tests the null hypothesis of non-correlation between non-observable individual effects and explanatory variables, as against the alternative hypothesis of correlation between non-observable individual effects and explanatory variables. 
Of particular interest are the results of the analysis of the determinants of HIIT and VIIT. What is apparent is that there are differences between the two equations and that these are masked by using a specification which looks only at IIT without any decomposition. The estimates obtained for the second model (HIIT) show that all explanatory variables are significant with exception of LogMaxGDP. The results are very similar to the IIT model estimated, highlighting the earlier observation that the IIT of the United States does tend to be predominately HIIT. The third equation (VIIT) has a lesser number of significant variables with some noticeable differences in sign in some cases.

The variable (LogDGDP) can be considered to capture supply side (relative differences in factor endowments) as well as demand side effects (relative differences in demand patterns). The results obtained are consistent with theoretical predictions. Differences in per capita income across trading partners exhibit a negative relationship with HIIT and IIT, but are positively related to VIIT. This is consistent with Zhang and Clark (2009) who found a similar result in the case of IIT and HIIT in their United States study based on 1997 data; however, they also found a significant and negative relationship for VIIT. The results here also conform to those of Leitão and Faustino (2008) and Helpman and Krugman (1985) who look at IIT, and Greenaway, Hine, and Milner (1994) and Crespo and Fontoura (2004) who distinguish between VIIT and HIIT. The United States' HIIT, therefore, is more likely to be with countries that are more similar in terms of development levels, while the converse is true for VIIT.

The above finding is reinforced by the signs of LogINT. VIIT is found to be positively related to this proxy reflecting the fact that this type of bilateral trade is driven by factors underlying relative comparative advantage. Similar forces are likely to be important determinants of both IT and VIIT. The sign for both IIT and HIIT is negative as predicted.

Following Helpman and Krugman (1985) the study included two variables to control for relative size effects. Of these, the variable (LogMINGDP) has the expected positive sign and is significant in all cases. These results accord with evidence found in Hummels and Levinsohn (1995) and Greenaway, Hine, and Milner (1994).

The proxy LogDIM that captures the impact of the size of the market in bilateral trade (from both a supply side and demand side perspective) is statistically significant and positively related to all dependent variables. This is as expected and is consistent with evidence from other studies (Umemoto 2005; Chemsripong, Lee and Agbola 2005; Leitão and Faustino 2009).

Significant positive relationships are established between the log of FDI and both IIT and HIIT, but there is no significant relationship evident for VIIT. This finding is in line with results by Zhang and Clark (2009) for United States' HIIT and a 
result from Zhang, van Witteloostuijin, and Zhou (2005) in a study of China's bilateral two-way trade. A positive link between FDI and IIT is also seen in Greenaway, Hine, and Milner (1994) while evidence from Yoshida, while Leitão and Faustino (2009) suggest that bilateral IIT is positively linked with inflows of Japanese FDI into partner countries. In a study of ASEAN trade Hurley (2003) has found a positive link between FDI and VIIT and a negative one with HIIT. Not surprisingly, results from different studies will vary and reflect the nature and type of FDI that pertain to particular situations. The evidence here suggest that significant amounts of United States' FDI is tied in with the offshore production of horizontally differentiated products which are then shipped back to the domestic market. FDI associated with the production of vertically different products for re-export is not seen to have been significant for the United States over the period.

The variable LogDISTxDGDP, has been used as a typical gravity model variable. Numerous studies have found evidence supporting the inverse linkage between geographic distance and IIT (Crespo and Fontoura 2004; Leitão and Faustino 2009, 2008; Bergstrand and Egger 2006). A negative relationship was expected in all cases, but significant results have only been found for IIT and HIIT. Zhang and Clark (2009) found similar results in their study of the United States. As noted above, the expectation was that this variable would likely be relatively more important for HIIT (Zhang, van Witteloostuijin, and Zhou 2005). The impact of United States trading agreements on HIIT with neighbouring countries, including existing and proposed agreements, may be a consideration for further study, particularly with respect to the issue of adjustment pressures (or relative lack thereof) engendered by such trade.

\section{Conclusion}

The objective of this paper is the analysis of country-specific determinants of bilateral IIT for the United States over the period 1995-2008. IIT was decomposed into HIIT and VIIT in order to shed light on the nature and pattern of IIT and determine to what extent different forces may be at play in driving United States' two-way trade.

Evidence suggests that two-way trade accounts for more than half of the total trade of the United States and is dominated by HIIT. There is some variability observed in the changes in HIIT and VIIT over the period, but results indicate that HIIT has tended to increase with respect to trade relations with neighbouring countries and with a major trading partner, China. Even where HIIT has fallen as a share of IIT, it remains very significant in most bilateral relationships. With reference to the "smooth adjustment hypothesis" a 
predominance of HIIT is likely to be accompanied by relatively less factor market adjustment pressures than would be the case with VIIT or IT. This is one area of United States' trade that needs further investigation.

Using pooled panel data the study identifies a number of factors that are significant influences on IIT, HIIT and VIIT. The results overall tend to conform with a priori expectations and provide empirical support for a number of propositions suggested by theory. Findings indicate that the relative similarity of the economies of trading partners, their geographical proximity, FDI and overall market size are important influences on bilateral HIIT flows for the United States. VIIT, on the other hand, is found to be driven in large part by economic differences between partners as well as the market size and closeness of trading partners.

The results highlight the importance in distinguishing between different types of IIT in empirical studies.

\section{Appendix}

Table 3: Descriptive statistics for IIT panel.

\begin{tabular}{lrrrr}
\hline Variables & Mean & St dev & Minimum & Maximum \\
\hline LogIIT & 10.37 & 0.55 & 9.24 & 11.72 \\
LogDGDP & 7.20 & 0.56 & 6.80 & 8.99 \\
LogMinGDP & 7.01 & 0.09 & 6.86 & 7.15 \\
LogMaxGDP & 4.97 & 1.51 & 3.18 & 9.00 \\
LogDIM & 7.18 & 0.47 & 6.87 & 8.71 \\
LogINT & 9.84 & 0.74 & 7.24 & 11.45 \\
LogFDI & 5.17 & 0.25 & 4.76 & 5.50 \\
LogDISTxDGDP & 28.99 & 6.27 & 24.01 & 54.38 \\
Observations: 252 & & & & \\
\hline
\end{tabular}

Table 4: Descriptive statistics for HIIT panel.

\begin{tabular}{lrrrr}
\hline Variables & Mean & St dev & Minimum & Maximum \\
\hline LogHIIT & 10.07 & 0.73 & 7.70 & 11.64 \\
LogDGDP & 7.20 & 0.56 & 6.80 & 8.99 \\
LogMinGDP & 7.01 & 0.09 & 6.86 & 7.15 \\
LogMaxGDP & 4.97 & 1.51 & 3.18 & 9.00 \\
LogDIM & 7.18 & 0.47 & 6.87 & 8.71 \\
LogINT & 9.84 & 0.74 & 7.24 & 11.45 \\
LogFDI & 5.17 & 0.25 & 4.76 & 5.50 \\
LogDISTxDGDP & 28.99 & 6.27 & 24.01 & 54.38 \\
Observations: 252 & & & & \\
\hline
\end{tabular}


Table 5: Descriptive statistics for VIIT panel.

\begin{tabular}{lcccr}
\hline Variables & Mean & St dev & Minimum & Maximum \\
\hline LogVIIT & 9.77 & 0.69 & 7.24 & 10.96 \\
LogDGDP & 7.20 & 0.56 & 6.80 & 8.99 \\
LogMinGDP & 7.01 & 0.09 & 6.86 & 7.15 \\
LogMaxGDP & 4.97 & 1.51 & 3.18 & 9.00 \\
LogDIM & 7.18 & 0.47 & 6.87 & 8.71 \\
LogINT & 9.84 & 0.74 & 7.24 & 11.45 \\
LogFDI & 5.18 & 0.252 & 4.76 & 5.50 \\
Observations: 252 & & & & \\
\hline
\end{tabular}

\section{References}

Abd-el-Rahuman, K. 1991. "Firm's competitive and National comparative advantages as joint determinants of trade composition." Weltwirtschaftliches Archiv 127(1):83-97.

Anderson, J. 1979. "A Theoretical Foundation for the Gravity Equation.” American Economic Review 69(1):106-16.

Anderson, J., and E. van Wincoop. 2004. "Trade Costs." Journal of Economic Literature 42:691-751.

Azhar, A., and R. Elliott. 2006. "On the Measurement of Product Quality in Intra-Industry Trade." Review of World Economics 142:476-95.

Balassa, B. 1966. "Tariff Reductions and Trade in Manufactures among the Industrial Countries." American Economic Review 56:466-73.

Balassa, B. 1986. "The Determinants of Intra-Industry Specialization in the United States." Oxford University papers:220-33.

Balassa, B., and L. Bauwens. 1987. "Intra-Industry Trade Specialization in a Multi-Country and Multi-Industry Framework." Economic Journal 97(388):923-39.

Bergstrand, J., and P. Egger. 2006. "Trade Costs and Intra-Industry Trade." Review of World Economics 14:433-58.

Blanes, J., and J. Martin-Montaner. 2006. "Migration Flows and Intra-Industry Trade Adjustments." Review of World Economics 142:567-84.

Brulhart, M., and R.J. Elliott. 2002. "Labour-Market Effects of Intra-Industry Trade: Evidence from the United Kingdom.” Welwirtschaftliches Archiv 138:207-28.

Brulhart, M., and M. Thorpe. 2001. "Export Growth of NAFTA Memebers, Intra-Industry trade and Adjustment." Global Business and Economic Review 30(1):94-110.

Chang, Shun-Chiao. 2009. "Horizontal and Vertical Intra-industry Trade and Firm's Investment Strategies: Evidence from the IT Industry in the Asian, EU and US Markets." Global Economic Review 38:63-76.

Chemsripong, S., J.E. Lee, and F.W. Agbola 2005. "Intra-Industry Trade in Manufactures between Thailand and Other Asia Pacific Economic Cooperation (APEC) Countries for 1980." Applied Econometrics and International Development 5:63-82.

Clark, D. 2006. "Country and Industry-Level Determinants of Vertical Specialization Based Trade." International Economic Journal 20(2):211-25. 
Clark, D., and D. Stanley. 2003. "Determinants of Intraindustry Trade between the United States and Industrial Nations." International Economic Journal 17:1-17.

Crespo, N., and M.P. Fontoura. 2004. "Intra-Industry Trade by Types: What Can We Learn from Portuguese Data?" Review of World Economics 140:52-76.

Darku, A. 2009. "The Gravity Model and the Test for the Regional Integration Effect: The Case of Tanzania." The Journal of Developing Areas 43(1):25-45.

Davis, D.R. 1995. “Intra-Industry Trade: A Heckscher-Ohlin-Ricardo Approach.” Journal of International Economics 39:201-26.

Eaton, J., and H. Kierzkowski. 1984. "Oligopolistic Competition, Product Variety, and International Trade." In Monopolistic Competition and International Trade, edited by H. Kierzkowski, pp. 247-308. New York: Oxford University Press.

Falvey, R.E. 1981. "Commercial Policy and Intra-Industry Trade." Journal of International Economics 11(4):494-511.

Falvey, R.E., and H. Kierzkowski. 1987. "Product Quality, Intra-Industry Trade and (Im)Perfect Competition." In Protection and Competition in International Trade, pp. 810-22. Oxford, UK: Basil Blackwell.

Faustino, H., and N.C. Leitão. 2007. "Intra-Industry Trade: A Static and Dynamic Panel Data Analysis." International Advances in Economic Research 13(3):313-33.

Fitzpatrick, G.L., and M. Modlin. 1986. Direct Line Distance, International Edition. Metucken, N): The Scarecrow Press.

Flam, H., and E. Helpman. 1987. "Vertical Product Differentiation and North-South-Trade." American Economic Review 77:810-22.

Fontagne, L., and M. Feudenberg. 1997. "Intra-Industry Trade: Methodological Issues Reconsidered.” CEPII Working Paper, 97/01, Center for International Prospective Studies and Information, Paris.

Fontagne, L., M. Freudenberg, and G. Gaulier. 2006. "A Systematic Decomposition of World Trade into Horizontal and Vertical IIT." Review of World Economics 142:459-75.

Gabriel, G. 1987. "Intra-Industry Trade Between Development and Developing Countries: The United States and the NICS." The Journal of Developing Areas 21(4):481-94.

Gray, H. 1988. “Intra- Industry Trade: An Untidy Phenomenon.” Weltwirtschaftliches Archiv 124:17-134.

Gray, H.P., and C. Martin. 1980. "The Meaning and Measurement of Product Differentiation in International Trade." Weltwirtschaftliches Archiv 116:322-9.

Greenaway, D., R. Hine, and C. Milner. 1994. "Country-Specific Factors and the Pattern of Horizontal and Vertical Intra-Industry Trade in the UK. Review of World Economics 130(1):77-100.

Greenway, D., and C. Milner. 2006. "Recent Developments in Intra-Industry Trade: Introduction by Guest Editors." Review of World Economics 142(3):425-32.

Greenway, D., and C. Milner. 2005. "What Have We Learned from a Generation's Research on Intra-Industry Trade?" In Trade Theory, Analytical Models and Development, edited by S. Jayashariya, pp. 254-276. London: Edward Elgar.

Grossman, G.M., and E. Helpman. 2005. "Outsourcing in a Global Economy." Review of Economic Studies 72:135-59.

Grubel, H., and P. Lloyd. 1975. Intra-Industry Trade: The Theory and Measurement of International Trade in Different Products. London: Macmillan.

Helpman, E. 1987. "Imperfect Competition and International Trade: Evidence from Fourteen Industrial Countries." Journal of the Japanese and International Economies 1:62-81. 
Helpman, E. 1981. "International Trade in the Presence of Product Differentiation, Economies of Scales and Monopolistic Competition: A Chamberlin-Heckscher-Ohlin Approach.” Journal of Political Economy 92:451-71.

Helpman, E., and P. Krugman. 1985. Market Structure and Foreign Trade: Increasing Returns, Imperfect Competition and the International Economy, 1st ed. London: MIT Press.

Hummels, D., and J. Levinsohn. 1995. "Monopolistic Competition and International Trade: Reconsidering the Evidence." Quarterly Journal of Economics 110(3):799-836.

Hurley, D. 2003. "Horizontal and Vertical Intra-Industry Trade: The Case of ASEAN Trade in Manufactures." International Economic Journal 17:1-14.

Jones, R., and H. Kierzkowski. 2004. "International Fragmentation and the New Economic Geography.” HEI Working Paper, 11/2004, Graduate Institute of International Studies, Geneva.

Kandogan, Y. 2003. "Intra-Industry Trade of Transition Countries: Trends and Determinants." Emerging Markets Review 4(3):272-86.

Krugman, P. 1979. “Increasing Returns, Monopolistic Competition and International Trade." Journal of International Economics 9(4):469-79.

Krugman, P. 1980. "Scale Economies, Product Differentiation and the Pattern of Trade." The American Economic Review 70(5):950-9.

Lancaster, K. 1980. "Intra-Industry Trade Under Perfect Monopolistic Competition." Journal of International Economics 10(2):151-75.

Leitão, N.C., and H. Faustino. 2008. "Intra - Industry Trade in the Food Processing Sector: The Portuguese Case." Journal of Global Business and Technology 4(1):49-58.

Leitão, N.C., and H. Faustino. 2009. "Intra-Industry Trade in the Automobile Components Industry: An Empirical Analysis." Journal of Global Business and Technology 5(1):31-41.

Leitão, N.C, H. Faustino, and Y. Yoshida. 2010. "Fragmentation, Vertical Intra-Industry Trade and Automobile Components." Economics Bulletin 30(2):1006-15.

Linder, S.B. 1961. An Essay on Trade and Transformation. New York: John Wiley.

Lloyd, P. 2004. "How Intra-Industry Trade Changed Our Perception of the World Economy." The Singapore Economic Review 49(11):1-17.

Loertscher, R., and F. Wolter. 1980. "Determinants of Intra-Industry Trade Among Countries and Across Industries." Review of World Economics 116(2):280-93.

Markusen, J.R. 1994. “Multinational Multiplant Economies and the Gains from Trade." Journal of International Economics 16(3,4):205-26.

McCloskey, D. 1988. The Rhetoric of Economics. University of Wisconsin Press, Madison, Wisconsin.

Murshed, S.M. 2001. "Patterns of East Asian Trade and Intra-Industry Trade in Manufactures." Journal of the Asia Pacific Economy 6(1):99-123.

OECD. 2010. "SITC Revision 3", International Trade by Commodity Statistics (database). doi: 10.1787/data-00054-en.

OECD. 2002. "Intra-Industry and Intra-Firm Trade and the Internationalization of Production." OECD Economic Outlook 71, Ch VI.

Shaked, A., and J. Sutton. 1984. "Natural Oligopolies and International Trade." In Monopolistic Competition and International Trade, edited by H. Kierzkowski, pp. 34-50. Oxford University Press.

Thom, R., and M. McDowell. 1999. "Measuring Marginal Intra-Industry Trade." Weltwirtschaftliches Archiv 135:48-61.

Thorpe, M., and Zhaoyang Zhang. 2005. "Study of the Measurement and Determinants of Intra-Industry Trade in East Asia.” Asian Economic Journal 19:231-47. 
Umemoto, M. 2005. "Development and Intra-Industry Trade between Korea and Japan: The Case of Automobile Parts Industry." CITS Working Paper no. 2005-03, Centre for International Trade Studies, Yokohama National University.

Verdoorn, P.J. 1960. "The Intra-Bloc Trade of Benelux.” In Economic Consequences of the Size of Nations, edited by E.A.G. Robinson, pp. 319-321. London: Macmillan.

Wakasugi, R. 2007. "Vertical Intra-Industry Trade and Economic Integration in East Asia." Asian Economic Papers 6:26-45.

Yoshida, Y., N.C. Leitão, and H. Faustino. 2009. "Vertical Intra-Industry Trade and Foreign Direct Investment between Japan and European Countries." Atlantic Economic Journal 37:351-65.

Zhang, Yanhong, and Don P. Clark. 2009. "Pattern and Determinants of United States' IntraIndustry Trade." The International Trade Journal 23(3):325-56.

Zhang, J., A. van Witteloostuijin, and C. Zhou. 2005. "Chinese Bilateral Intra-Industry Trade: A Panel Data Study for 50 Countries in the 1992-2001 Period." Review of World Economics 141:510-40. 
Copyright of Global Economy Journal is the property of De Gruyter and its content may not be copied or emailed to multiple sites or posted to a listserv without the copyright holder's express written permission. However, users may print, download, or email articles for individual use. 